\title{
Penggunaan Singkatan dalam Penulisan Ilmiah
}

\section{Enie Novieastari Mukti}

Dosen Keperawatan dasar FIK-UI

Singkatan dari suatu istilah dalam tulisan ilmiah seringkali digunakan oleh penulis. Untuk memaksimalkan kejelasan naskah dan pengertian bacaan, penulis perlu memperhatikan beberapa hal yang dapat dijadikan pedoman dalam penggunaan singkatan menurut “American Psychological Association (APA)” yang banyak dipaki sebagai penuntun dalam penulisan ilmiah.

Kata kunci : Singkatan; istilah

The writers sometimes use abbreviations in their paper. In order to maximize the comprehensiveness of the paper, there are some guidance based on the American Psychological Association (APA), which could be used.

Key words : Abbreviation; terms. 